\title{
RANCANG BANGUN APLIKASI PENDUKUNG PEMBELAJARAN ILMU PENGETAHUAN SOSIAL (IPS) SEKOLAH DASAR BERBASIS ANDROID
}

\author{
(Design and Development of Supporting Applications for Android-based Primary \\ School Social Studies Learning)
}

Dinda Bahari Putri, Sri Endang Anjarwani ${ }^{*}$, Royana Afwani

Program Studi Teknik Informatika, Fakultas Teknik, Universitas Mataram

Jl. Majapahit 62, Mataram, Lombok NTB, INDONESIA

Email: dindabahariputri@gmail.com, endang@unram.ac.id, royana@unram.ac.id

\begin{abstract}
IPS is a lesson at the elementary school level. Based on the curriculum at SDN 22 Ampenan which uses the 2006 KTS curriculum, each student learns to use the media of LKS and books as the supporting media. The availability of the media has less influence on students. The purpose of this study is to help the learning process of students with multimedia available in the application. This application features materials, pictures, videos and evaluations contained in exercises and games in every IPS lesson chapter in grades 5 and 6. This application is built using android studio version 2.2.1 with the Java programming language. Besides this application is also developed using the waterfall model. The testing method used is black box and MOS testing. Testing using the MOS method on application.quality.shows.that.62.5\%.of.the respondents stated strongly agree, teacher respondents stated strongly agree with the percentage of $62.75 \%$.
\end{abstract}

Keywords: IPS, android based application, waterfall, black box and MOS

*Penulis korespondensi

\section{Pendahuluan}

Pembelajaran merupakan suatu kegiatan yang mencakup kegiatan belajar dan mengajar. Kegiatan pembelajaran mencakup metode pembelajaran, media pembelajaran, evaluasi pembelajaran, dan umpan balik pembelajaran. Salah satu pelajaran pada tingkat Sekolah Dasar (SD) yaitu Ilmu Pengetahuan Sosial (IPS)[1].

Dalam penelitian ini studi kasus dilakukan di SD Negeri 22 Ampenan yang proses pembelajaran nya menggunakan kurikulum KTSP 2006. Proses pembelajaran IPS di SD ini yaitu Lembar Kerja Siswa

(LKS) sebagai bahan dan papan tulis sebagai alat. Pada setiap pertemuan pembelajaran IPS, LKS ini digunakan sebagai media pendukung proses belajar. Berdasarkan wawancara yang dilakukan terhadap guru ke SDN 22 Ampenan, tersedianya media LKS dan papan tulis sebagian besar kurang berpengaruh terhadap peserta didik dalam proses belajar karena pada LKS tersebut terlalu banyak teks, serta sedikit gambar yang menjadikan peserta didik menjadi jenuh untuk belajar dan juga terdapat beberapa faktor. diantaranya penyampaian materi yang monoton, peserta didik yang tidak Memperhatikan saat proses belajar, banyaknya materi yang berupa bacaan, proses belajar yang masih menggunakan metode lama yaitu menyimak dan menulis ulang yang disampaikan guru sehingga faktor- faktor ini menyebabkan peserta didik menjadi jenuh dan mengakibatkan peserta didik mengalami kesulitan dalam memahami setiap materi.

Pada perkembangan teknologi saat ini, banyak di jumpai media pembelajaran seperti aplikasi android. Aplikasi android yang telah berkembang menawarkan berbagai kemudahan bagi peserta didik. Apalagi dari pihak sekolah SDN 22 Ampenan sangat mendukung adanya aplikasi android tersebut dalam menunjang proses belajar bagi peserta didik.

Berdasarkan latar belakang di atas, maka pada tugas akhir ini akan dirancang dan dibuat sebuah aplikasi android pendukung pembelajaran IPS SD yang dapat digunakan oleh peserta didik. Diharapkan penggunaan teknologi informasi dapat membantu mengatasi faktor-faktor penyebab peserta didik menjadi jenuh. Manfaat teknologi dalam dunia pendidikan adalah sebagai salah satu sarana informasi yang sangat mendukung dalam proses 
belajar peserta didik. Teknologi yang digunakan pada penelitian ini berupa aplikasi bergerak. Dalam lingkungan sekolah, aplikasi ini dapat dimanfaatkan untuk mendukung proses pembelajaran, sebagai pendukung belajar di bidang pendidikan IPS.

\section{TINJAUAN PUSTAKA}

Game edukasi ilmu pengetahuan alam untuk anak kelas VI sekolah dasar dengan tampilan menu pada aplikasi ini yaitu materi, permainan, dan petunjuk. Hasil dari aplikasi ini yaitu peserta didik bisa belajar lebih menyenangkan dibandingkan metode belajar yang lama serta mampu memberi modifikasi siswa agar lebih semangat dalam belajar. Aplikasi digunakan pada mobile yang berbasis java [2].

Aplikasi pembelajaran ilmu tajwid dengan menggunakan metode penelitiannya yaitu pengumpulan data, observasi, wawancara, dan kuesioner. Hasil aplikasi ini yaitu aplikasi dilengkapi dengan gambar, suara, dan kuis. Serta pengguna bisa menggunakan aplikasi dengan mudah Aplikasi diimplementasikan Menggunakan software eclipse [3].

Aplikasi pembelajaran kepada anak-anak tentang ilmu pembelajaran membaca, diimplementasikan pada software android studio. Hasil dari aplikasi yaitu menyediakan fitur belajar dengan berbagai macam pilihan dan latihan serta desain interface yang menarik sehingga menjadikan aplikasi sebagai media pembelajaran yang menarik sesuai pada kebutuhan anak-anak [4].

Aplikasi game edukasi mata pelajaran ilmu pengetahuan alam dan ilmu pengetahuan sosial dengan menyediakan beberapa fitur. Hasil aplikasi yaitu penggunaan interface yang menarik dengan dukungan beberapa data yang ada pada aplikasi yaitu berupa data audio, teks, animasi dan kuis sehingga anak-anak lebih tertarik lagi untuk mengulas pelajaran IPA dan IPS di rumah[5].

Aplikasi pembelajaran dan evaluasi ilmu pengetahuan alam untuk kelas 5 sekolah dasar. Hasil aplikasi yaitu aplikasi dapat mengevaluasi diri dengan memainkan permainan setiap bab dan evaluasi akhir setiap semester serta aplikasi dapat di akses secara online dan offline. Implementasi aplikasi menggunakan Laravel serta representasi state transfer. Penyajian dalam aplikasi berbentuk animasi berupa text, gambar dan video. Hasil dari pengujian aplikasi dengan menggunakan metode MOS yaitu responden dari guru sebesar $72 \%$ dan murid $48,77 \%$ menjawab setuju dengan aplikasi edukasi pembelajaran IPA ini[6].

Sistem informasi pembelajaran dibangun sebagai media alternatif dalam pembelajaran untuk anak retardasi mental setingkat SDLB C. Sistem pembelajaran berbasis android, sehingga anak retardasi mental dapat belajar dan menjawab latihan dimana saja dan kapan saja melalui smartphone dengan tampian kolaborasi teks, gambar, dan suara. Selain itu juga menghasilkan laporan nilai siswa dan peringkat berdasarkan hasil nilai yang didapat oleh siswa serta menampilkan output perkembangan siswa berdasarkan nilai dalam bentuk grafik [7]

Berdasarkan tinjauan pustaka di atas, dengan adanya aplikasi yang telah ada yaitu aplikasi edukasi ilmu pengetahuan alam dan ilmu pengetahuan sosial, maka pada tugas akhir ini penulis juga akan merancang aplikasi pendukung pembelajaran IPS Sekolah Dasar berbasis android, di Sekolah Dasar Negeri 22 Ampenan. Adapun kelebihan yang akan disajikan dalam aplikasi yaitu sebagai berikut:

1. Proses pendukung belajar dalam aplikasi disajikan dengan bentuk seperti teks, gambar, video, latihan atau kuis, dan permainan.

2. Permainan dan latihan yang disajikan dalam aplikasi yaitu berupa permainan tebak gambar, jumlah soal pada permainan ini sebanyak 10 soal dan terdapat waktu selama 60 detik untuk menjawab semua soal, hasil pada permainan ini berupa nilai dan pengguna menginputkan nama untuk melihat daftar 5 nilai terbaik. Sedangkan pada latihan atau kuis terdapat 10 soal dengan 4 pilihan jawaban yang mana untuk menjawab pada setiap soal memiliki waktu selama 20 detik, hasil dari latihan berupa nilai dari peserta didik yang mana jika nilai lebih dari 70 maka aplikasi akan menampilkan anda telah berhasil memahami materi tersebut.

\section{Metode Penelitian}

Penelitian aplikasi yang digunakan pada aplikasi pendukung pembelajaran IPS SD berbasis android yaitu model waterfall. Model waterfall dapat dilihat pada Gambar 1.

Metode penelitian ini yaitu metode. (waterfall model) memberikan sebuah pendekatan pengembangan sistem yang sistematik dan sekuensial, dimulai pada fase analisis, perencanaan sistem, implementasi, pengujian dan pemeliharaan [7]. 


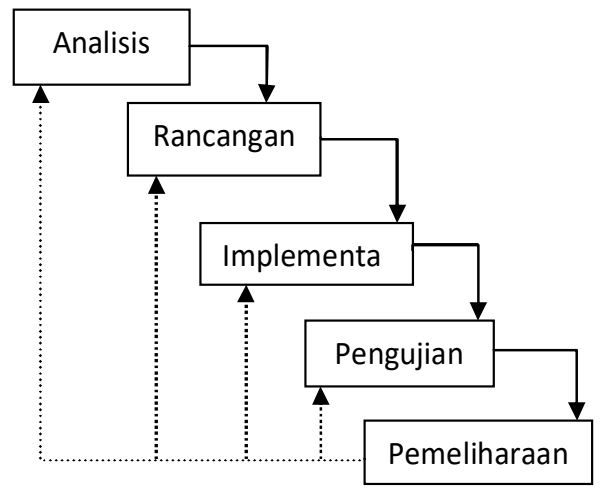

Gambar 1.Model pengembangan sistem waterfall

\subsection{Analisis Kebutuhan}

Tahap ini dilakukan observasi dan wawancara pada SDN 22 Ampenan yang bertujuan untuk memahami kebutuhan perangkat lunak yang sesuai harapan pengguna. Pada tahap ini diperoleh data yang berupa silabus pembelajaran IPS dan buku pembelajaran kelas 5 dan kelas 6, dalam memenuhi kebutuhan aplikasi pendukung pembelajaran IPS dan batasan perangkat lunak tersebut.

\subsection{Perancangan Usecase}

Tahap ini merupakan perancangan usecase yang menggambarkan proses yang dapat dilakukan oleh pengguna yaitu peserta didik. Perancangan usecase dilakukan agar para pengguna mengetahui prosesproses apa saja yang dapat dilakukan di dalam aplikasi ini. Perancangan usecase dapat dilihat pada Gambar 2.

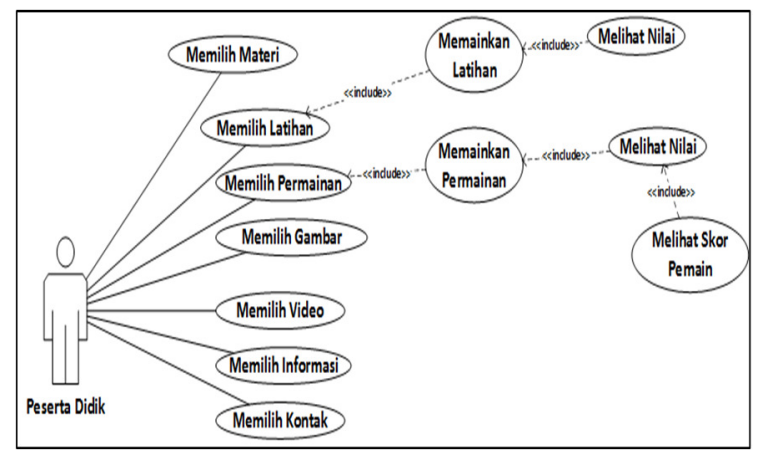

Gambar 2. Perancangan usecase

\subsection{Perancangan Database}

Tahap ini merupakan tahap perancangan database, data-data yang ada pada aplikasi pendukung pembelajaran IPS SD ini seluruhnya akan disimpan dalam satu database, sehingga data menjadi terintegrasi. Adapun Perancangan database dengan menggunakan ERD (Entity Relationship Diagram) dapat dilihat pada Gambar 3.

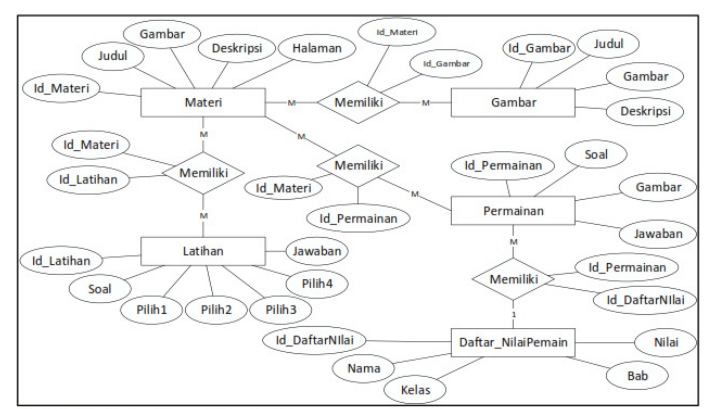

Gambar 3. ERD aplikasi pendukung pembelajaran IPS SD

\section{HASIL dAN PEMBahasan}

\subsection{Implementasi Interface}

Pada implementasi aplikasi terdapat beberapa tampilan interface. Berikut hasil dari implementasi interface dapat dilihat pada Gambar 4 sampai Gambar 10.
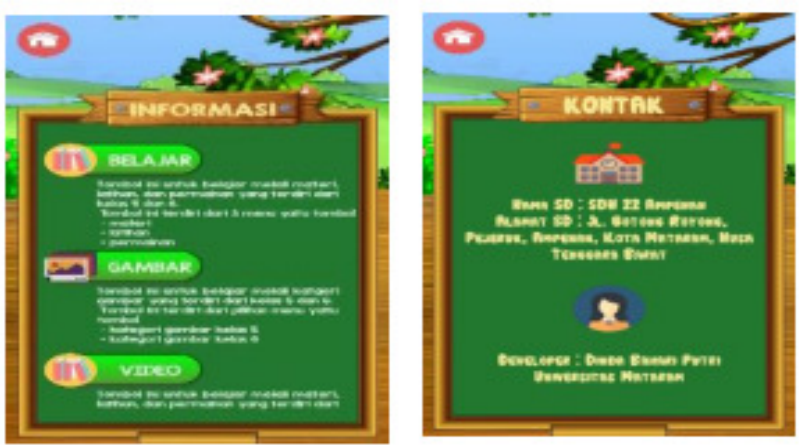

Gambar 4. Implementasi tampilan splash dan beranda

Gambar 4 terdiri dari halaman splash screen dan halaman beranda dimana pada halaman beranda terdapat pilihan menu belajar, gambar, video, informasi, dan kontak.
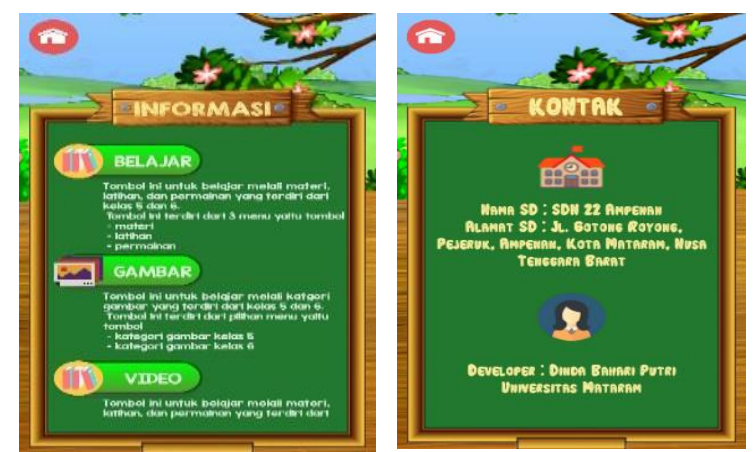

Gambar 5. Implementasi tampilan informasi dan kontak 

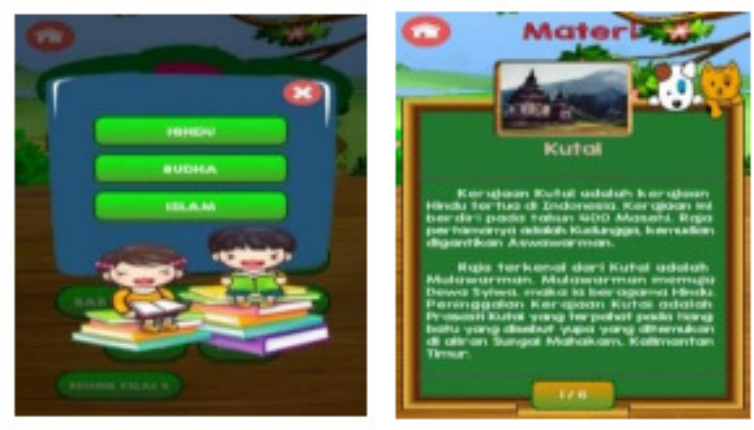

Gambar 6. Implementasi tampilan dialog menu materi

Gambar 5 terdiri dari tampilan halaman informasi dan kontak. Pada tampilan informasi menunjukkan Informasi tentang aplikasi. Pada tampilan kontak menampilkan biodata dari sekolah dan biodata dari pembuat aplikasi.

Gambar 6 terdiri dari halaman dialog menu materi dan materi. Pada tampilan materi menampilkan judul dan isi dari materi tersebut.

Gambar 7 terdiri dari halaman dialog latihan, latihan, dan hasil latihan. Pada halaman dialog terdapat pilihan untuk memulai latihan atau tidak, jika memilih ya maka dilanjutkan pada halaman untuk mengisi setiap soal yang ditampilkan dengan durasi watu setiap soal 20 detik pada halaman latihan. Setelah pengguna menjawab semua soal maka akan melanjutkan halaman selanjutnya yaitu halaman hasil latihan yang menunjukkan jika pengguna telah mendapatkan hasil lebih dari 70 maka akan berhasil untuk menguasai materi tersebut.
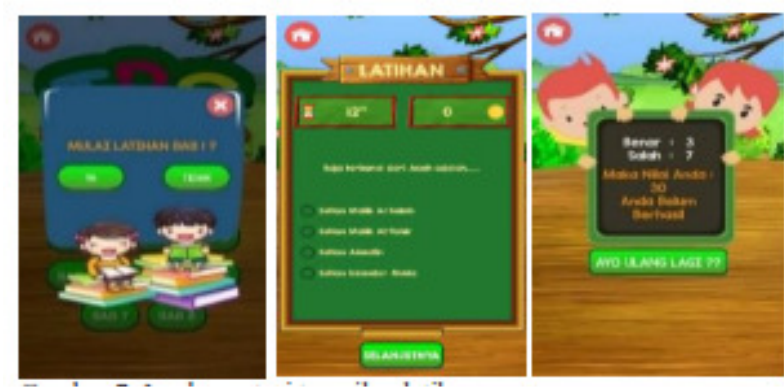

Gambar 7. Implementasi tampilan latihan

Gambar 8 terdiri dari halaman permainan, hasil permainan, dan daftar nilai pemain. Pada halaman permainan pengguna menjawab nama dari gambar yang menjadi soal serta terdapat waktu untuk menjawab semua soal selama 60 detik dan terdapat point, jika waktu telah selesai maka selanjutnya ke halaman hasil permainan yang mana menampilkan nilai dari pengguna, pada halaman ini terdapat kotak untuk menginputkan nama dari pemain, setelah itu dilanjutkan pada halaman daftar nilai pemain yang menampilkan 5 nilai terbaik dari permainan.
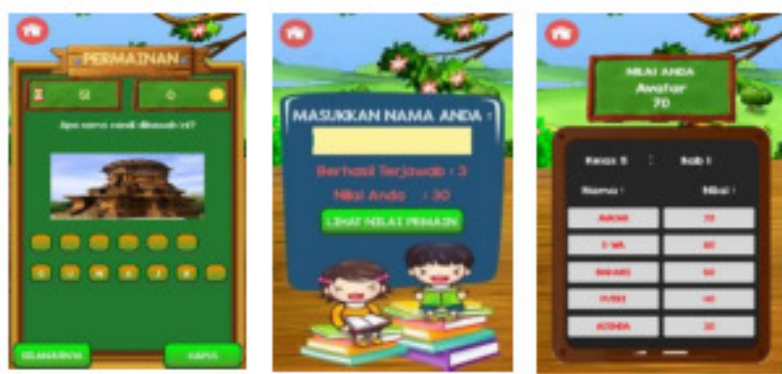

Gambar 8. Implementasi tampilan permainan

Gambar 9 terdiri dari halaman pilihan menu kategori gambar, gambar, dan deskripsi gambar. Pada menu kategori gambar jika pengguna memilih salah satu menu, maka akan dilanjutkan pada halaman untuk menampilkan gambar-gambar tersebut, selanjutnya pengguna bisa memilih salah satu gambar untuk menuju pada halaman deskripsi tentang gambar tersebut atau gambar yang dipilih.

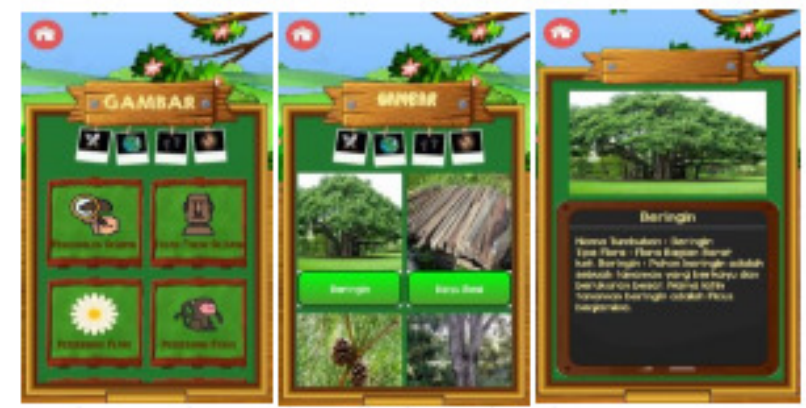

Gambar 9. Implementasi tampilan kategori gambar
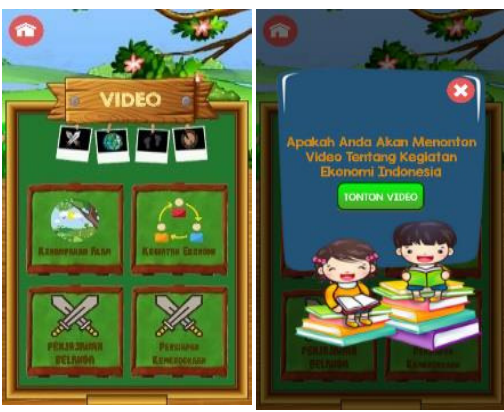

Kegiatan Elonomidi ladonet

Gambar 10 Implementasi tampilan kategori video

Gambar 10 terdiri dari halaman menu kategori video, dialog video, dan memulai video. Pada menu video kategori video jika pengguna memilih salah satu menu, maka akan dilanjutkan pada halaman dialog video untuk menonton video tersebut dapat dilakukan pada halaman memulai video dengan syarat jika hp android telah terhubung dengan koneksi internet.

\subsection{Pengujian Aplikasi}

Ada dua pengujian yang dilakukan pada penelitian ini, yaitu: 
1. Pengujian Black Box, Metode pengujian black box merupakan metode pengujian yang menguji fungsi-fungsi di dalam aplikasi pendukung pembelajaran IPS SD, untuk mengetahui apakah fungsi-fungsi yang ada sesuai harapan atau tidak. Hasil pengujian black box menunjukkan semua fungsi yang ada dalam aplikasi ini telah berjalan dengan baik.

2. Pengujian MOS, yang dilakukan dengan membagikan kuesioner terhadap pengguna aplikasi untuk mengetahui kualitas dari aplikasi pendukung pembelajaran IPS dan kesesuaian muatan materi pada aplikasi.

\subsubsection{Pengujian Terhadap Kualitas Aplikasi}

Pengujian MOS dilakukan pada peserta didik dan guru, responden dari peserta didik yang terdiri dari 20 peserta didik, dan responden dari guru terdiri dari 3 guru pengujian dilakukan pada SDN 22 Ampenan. Adapun kuesioner pengujian terhadap kualitas aplikasi adalah sebagai berikut :

Kuesioner pengujian untuk peserta didik terdiri dari 6 pertanyaan, yaitu :

a. Apa kesan ketertarikan anda saat menggunakan aplikasi?

b. Apakah aplikasi mudah digunakan?

c. Apakah tampilan dari aplikasi menarik?

d. Apakah penggunaan warna dan huruf pada aplikasi menarik?

e. Apakah tombol pada setiap aplikasi mudah dimengerti?

f. Apakah aplikasi ini menambah pengetahuan anda?

Kuesioner pengujian untuk guru terdiri dari 8 pertanyaan, yaitu :

a. Apa kesan ketertarikan anda saat menggunakan aplikasi?

b. Apakah aplikasi mudah digunakan?

c. Apakah konsep dari aplikasi menarik?

d. Apakah tampilan dari aplikasi menarik?

e. Apakah menu dan sub menu pada aplikasi mudah dipahami?

f. Apakah penggunaan warna dan huruf pada aplikasi menarik?

g. Apakah tombol pada setiap aplikasi mudah dimengerti?

h. Apakah musik menarik sebagai background pada aplikasi?
Berikut ini bobot nilai untuk setiap Response alternative ditunjukkan pada Tabel I.

TABEL I. BOBOT NILAI

\begin{tabular}{|c|c|}
\hline Nilai/Respone Alternative & Nilai Bobot \\
\hline 5(Sangat Setuju) & 5 \\
\hline 4 (Setuju) & 4 \\
\hline 3 (Cukup) & 3 \\
\hline 2 (Kurang Setuju) & 2 \\
\hline 1 (Tidak Setuju) & 1 \\
\hline
\end{tabular}

Hasil pengujian responden dari peserta didik terhadap kualitas aplikasi, ditunjukkan pada Tabel II.

TABEL II. HASIL PENGUJIAN KUESIONER Untuk Responden PESERTA DIDIK

\begin{tabular}{|c|c|c|c|c|c|c|}
\hline \multirow{2}{*}{ Pertanyaan } & \multicolumn{5}{|c|}{ Bobot Nilai } & \multirow{2}{*}{$\begin{array}{c}\text { Jumlah } \\
\text { Responden }\end{array}$} \\
\cline { 2 - 7 } & $\mathbf{5}$ & $\mathbf{4}$ & $\mathbf{3}$ & $\mathbf{2}$ & $\mathbf{1}$ & \\
\hline 1 & 20 & 0 & 0 & 0 & 0 & 20 \\
\hline 2 & 11 & 8 & 1 & 0 & 0 & 20 \\
\hline 3 & 16 & 4 & 0 & 0 & 0 & 20 \\
\hline 4 & 14 & 6 & 0 & 0 & 0 & 20 \\
\hline 5 & 11 & 7 & 2 & 0 & 0 & 20 \\
\hline 6 & 3 & 13 & 4 & 0 & 0 & 20 \\
\hline
\end{tabular}

Hasil rata-rata dari semua pertanyaan pada peserta didik untuk penilaian kualitas aplikasi, ditunjukkan pada Tabel III.

TABEL III. HASIL RATA-RATA PERSENTASE SEMUA.PERTANYAAN

\begin{tabular}{|c|c|}
\hline Sangat Setuju & $62.5 \%$ \\
\hline Setuju & $31.67 \%$ \\
\hline Cukup & $0 \%$ \\
\hline Kurang Setuju & $0 \%$ \\
\hline Tidak Setuju & \\
\hline
\end{tabular}

Hasil pengujian responden dari guru terhadap kualitas aplikasi, ditunjukkan pada Tabel IV.

TABEL IV. HAsil Pengujian Kuesioner Untuk Responden GURU

\begin{tabular}{|c|c|c|c|c|c|c}
\hline \multirow{2}{*}{ Pertanyaan } & \multicolumn{5}{|c|}{ Bobot Nilai } & \multirow{2}{*}{$\begin{array}{c}\text { Jumlah } \\
\text { Responden }\end{array}$} \\
\cline { 2 - 6 } & $\mathbf{5}$ & $\mathbf{4}$ & $\mathbf{3}$ & $\mathbf{2}$ & $\mathbf{1}$ & 3 \\
\hline 1 & 2 & 1 & 0 & 0 & 0 & 3 \\
\hline 2 & 2 & 1 & 0 & 0 & 0 & 3 \\
\hline 3 & 2 & 1 & 0 & 0 & 0 & 3 \\
\hline 4 & 2 & 1 & 0 & 0 & 0 & 3 \\
\hline 5 & 1 & 2 & 0 & 0 & 0 & 3 \\
\hline 6 & 2 & 1 & 0 & 0 & 0 & 3 \\
\hline 7 & 3 & 0 & 0 & 0 & 0 & 3 \\
\hline 8 & 1 & 1 & 1 & 0 & 0 & \\
\hline
\end{tabular}


TABEL V. Hasil Rata-Rata Persentase Semua Pertanyaan

\begin{tabular}{|c|c|}
\hline Sangat Setuju & $62.75 \%$ \\
\hline Setuju & $33.125 \%$ \\
\hline Cukup & $4.125 \%$ \\
\hline Kurang Setuju & $0 \%$ \\
\hline Tidak Setuju & $0 \%$ \\
\hline
\end{tabular}

Hasil rata-rata dari semua pertanyaan pada guru untuk penilaian kualitas aplikasi, ditunjukkan pada Tabel V.

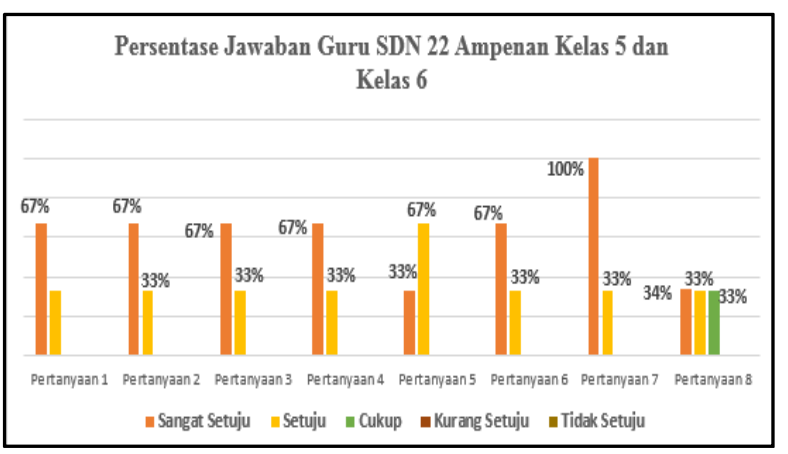

Gambar 10. Grafik jawaban responden peserta didik

Gambar 10 merupakan grafik hasil dari penilai MOS peserta didik terhadap kualitas aplikasi pendukung pembelajaran IPS, terlihat pada gambar untuk peserta didik dengan persentase total pada aplikasi penilaian sangat setuju sebesar $62.5 \%$.

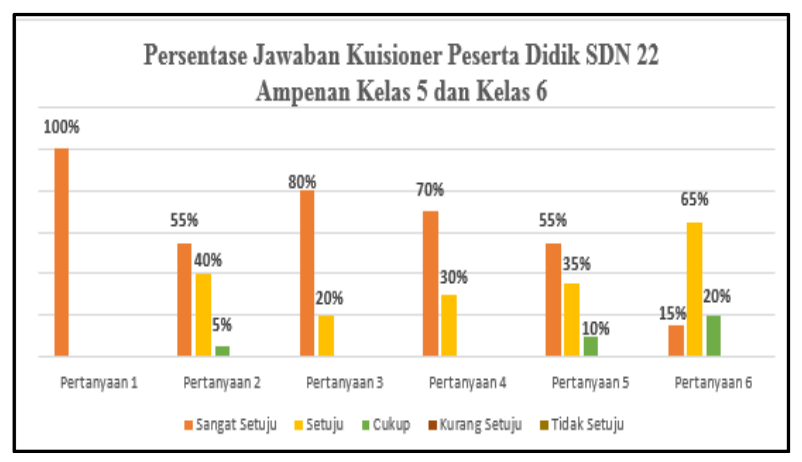

Gambar 11 Grafik jawaban responden guru

Gambar 11 merupakan grafik hasil dari penilai MOS guru terhadap kualitas aplikasi pendukung pembelajaran IPS, terlihat pada gambar untuk guru dengan persentase total pada aplikasi penilaian sangat setuju sebesar $62,75 \%$.

\subsubsection{Pengujian Terhadap Kualitas Materi}

Selanjutnya Pengujian ini dilakukan oleh ahli materi yaitu guru. Adapun responden guru terdiri dari guru kelas 5 yang terdiri dari 1 guru dan 6 yang terdiri dari 2 guru, materi yang di uji yaitu materi kelas 5 dan kelas 6 yang mana menggunakan kurikulum dari SDN 22 Ampenan yaitu KTSP 2006. pengujian dilakukan pada SDN 22 Ampenan. Adapun kuesioner untuk pengujian muatan materi pada aplikasi adalah sebagai berikut.

Kuesioner pengujian untuk guru kelas 5 dan 6 yang terdiri dari 5 pertanyaan, yaitu:

a. Apakah materi pada aplikasi tentang bab ini telah mencakup pada materi yang diajarkan?

b. Apakah latihan pada aplikasi bab ini telah sesuai dari materi yang telah dipaparkan pada aplikasi?

c. Apakah permainan pada aplikasi bab ini telah sesuai dari materi yang telah dipaparkan pada aplikasi?

d. Apakah penyajian dalam kategori gambar pada aplikasi sudah mencakup materi?

e. Apakah penyajian dalam kategori video pada aplikasi sudah mencakup materi?

Hasil pengujian terhadap muatan materi kelas 5 dari guru kelas 5, ditunjukkan pada Tabel VI.

TABEL VI. Hasil PenguJian Responden GuRU Kelas5.PADA MuATAN MATERI KeLAS 5

\begin{tabular}{|c|c|c|c|c|c|c|c|c|}
\hline & \multicolumn{8}{|c|}{ Persentase } \\
\hline & $\begin{array}{c}\text { Bab } \\
1 \\
\end{array}$ & $\begin{array}{c}\text { Bab } \\
\mathbf{2}\end{array}$ & $\begin{array}{c}\text { Bab } \\
\mathbf{3}\end{array}$ & $\begin{array}{c}\text { Bab } \\
4 \\
\end{array}$ & $\begin{array}{c}\text { Bab } \\
5\end{array}$ & $\begin{array}{c}\text { Bab } \\
6 \\
\end{array}$ & $\begin{array}{c}\text { Bab } \\
7\end{array}$ & $\begin{array}{c}\text { Bab } \\
8 \\
\end{array}$ \\
\hline $\begin{array}{l}\text { Sangat } \\
\text { Setuju }\end{array}$ & $\begin{array}{l}20 \\
\%\end{array}$ & & $20 \%$ & & & & & \\
\hline Setuju & $\begin{array}{l}80 \\
\% \\
\end{array}$ & $\begin{array}{r}100 \\
\%\end{array}$ & $60 \%$ & $\begin{array}{r}100 \\
\% \\
\end{array}$ & $\begin{array}{c}100 \\
\%\end{array}$ & $\begin{array}{r}100 \\
\%\end{array}$ & $\begin{array}{r}100 \\
\%\end{array}$ & $\begin{array}{c}100 \\
\%\end{array}$ \\
\hline Cukup & & & $20 \%$ & & & & & \\
\hline $\begin{array}{l}\text { Kurang } \\
\text { Setuju }\end{array}$ & & & & & & & & \\
\hline $\begin{array}{l}\text { Tidak } \\
\text { Setuju }\end{array}$ & & & & & & & & \\
\hline
\end{tabular}

Hasil pengujian terhadap muatan materi kelas 6 dari guru kelas 6, ditunjukkan pada tabel 7.

TABEL VII. hasil Pengujian Responden Guru. Pada MuATAN MATERI Kelas 6

\begin{tabular}{|c|c|c|c|c|c|c|c|}
\hline & \multicolumn{7}{|c|}{ Persentase } \\
\cline { 2 - 8 } & $\begin{array}{c}\text { Bab } \\
\mathbf{1}\end{array}$ & $\begin{array}{c}\text { Bab } \\
\mathbf{2}\end{array}$ & $\begin{array}{c}\text { Bab } \\
\mathbf{3}\end{array}$ & $\begin{array}{c}\text { Bab } \\
\mathbf{4}\end{array}$ & $\begin{array}{c}\text { Bab } \\
\mathbf{5}\end{array}$ & $\begin{array}{c}\text { Bab } \\
\mathbf{6}\end{array}$ & $\begin{array}{c}\text { Bab } \\
\mathbf{7}\end{array}$ \\
\hline $\begin{array}{c}\text { Sangat } \\
\text { Setuju }\end{array}$ & $10 \%$ & $20 \%$ & $30 \%$ & $10 \%$ & $10 \%$ & $20 \%$ & \\
\hline Setuju & $80 \%$ & $70 \%$ & $60 \%$ & $90 \%$ & $80 \%$ & $80 \%$ & $90 \%$ \\
\hline Cukup & $10 \%$ & $10 \%$ & $10 \%$ & & $10 \%$ & & $10 \%$ \\
\hline $\begin{array}{c}\text { Kurang } \\
\text { Setuju }\end{array}$ & & & & & & & \\
\hline $\begin{array}{c}\text { Tidak } \\
\text { Setuju }\end{array}$ & & & & & & & \\
\hline
\end{tabular}




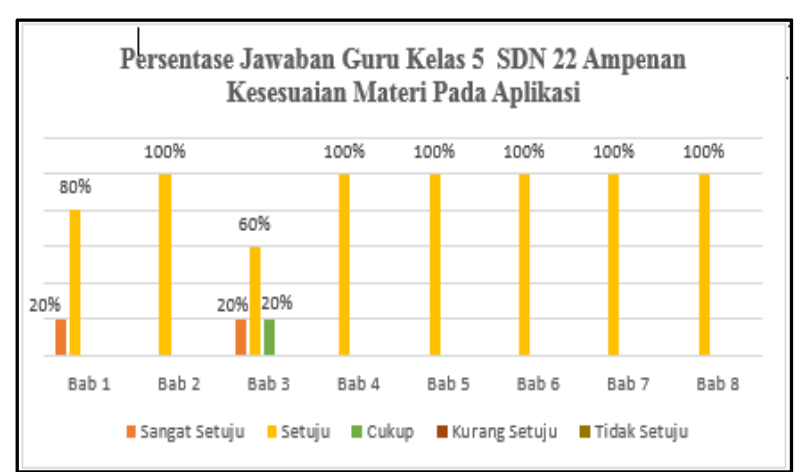

Gambar 12 Grafik jawaban responden guru kelas 5

Gambar 12 merupakan grafik hasil dari penilai MOS guru terhadap kesesuaian muatan materi kelas 5 pada aplikasi pendukung pembelajaran IPS, terlihat pada gambar persentase total untuk semua materi dengan penilaian setuju sebesar $92.5 \%$.

\section{KESIMPULAN DAN SARAN}

\subsection{Kesimpulan}

Berdasarkan hasil pembahasan dan pengujian yang dilakukan maka dapat ditarik kesimpulan dalam pembangunan "Aplikasi Pendukung Pembelajaran IPS SD" sebagai berikut:

1 Aplikasi ini berisi data materi untuk kelas 5 dan 6 pada SDN 22 Ampenan yang menggunakan kurikulum belajar KTSP 2006, dan dirancang menggunakan ERD, class diagram, use case diagram, sequence diagram, dan activity diagram.

2 Aplikasi.pendukung.pembelajaran.IPS.SD.ini memiliki menu yang terdiri dari menu belajar, menu kategori gambar, menu kategori video, menu informasi, dan menu kontak. Aplikasi juga memiliki menu untuk evaluasi yaitu pada menu latihan dan permainan yang ada pada menu belajar.

3 Aplikasi pendukung pembelajaran IPS SD ini telah diuji menggunakan metode pengujian black box dengan hasil uji semua fungsi yang diharapkan berhasil dan metode pengujian MOS ( Mean Opinion Score) yang dilakukan terhadap 20 responden peserta.didik,.serta.3.responden guru kelas 5 dan 6 pada SDN 22 Ampenan dengan hasil untuk kualitas aplikasi pendukung pembelajaran IPS untuk responden peserta didik dengan kriteria penilaian Sangat Setuju adalah $62.5 \%$ dan guru yaitu dengan nilai Sangat Setuju $62.75 \%$.

4 Hasil pengujian menggunakan metode MOS untuk kesesuaian muatan materi pada kelas 5 dengan rata- rata bernilai $92,5 \%$ setuju dan hasil materi pada kelas 6 dengan rata-rata bernilai 78,58\% setuju.

\subsection{Saran}

Adapun saran yang dapat disampaikan ke pengembang selanjutnya untuk pengembangan aplikasi pendukung pembelajaran IPS adalah sebagai berikut:

1. Dapat menciptakan aplikasi edukasi IPS pada tingkat SD dengan materi serta evaluasi secara online.

2. Aplikasi hanya mencakup materi yang ada pada kelas 5 dan kelas 6 , diharapkan ke depannya memiliki semua materi pada tingkat satuan sekolah dasar.

3. Aplikasi ini hanya bisa digunakan pada satu platform yaitu android, maka dari itu pengembang selanjutnya dapat membuat aplikasi ini bisa digunakan pada beberapa platform.

\section{DAfTAR PUSTAKa}

[1] N. Supriatna, Konsep Dasar IPS. Bandung: Grafindo, 2009.

[2] Y. Siswanto, dan B.E. Purnama, "Rancang Bangun Aplikasi Media Mobile Ilmu Pengetahuan Alam Untuk Anak Kelas VI Sekolah Dasar," Journal Speed-Sentra Penelitian Engineering dan Edukasi, Vol. 5, No. 4, 2013.

[3] D. Permatasari, dan A. Falah, "Aplikasi Pembelajaran Ilmu Tajwid Berbasis Android (studi kasus : madrasah ar - rahman bandung, Jurnal informasi dan teknologi," UNIKOM, Vol. 1, No. 7, 2013.

[4] J.T. Ali dan A. Patombang, "Perancangan Game Edukasi Pembelajaran Membaca Berbasis Android," Jurnal Sistem Informasi dan Teknik Komputer Catur Sakti, Vol. 1, No. 1, 2016

[5] P.I. Sari, dan B. E. Purnama, "Game Edukasi Mata Pelajaran IImu Pengetahuan Alam dan IImu Pengetahuan Sosial (IPS) Pada Sekolah Dasar Negeri Sooka 1 Panung Kabupaten Pacitan," Journal SpeedSentra Penelitian Enginering dan Edukasi, Vol. 7, No.1, 2015

[6] T. Maharani, Aplikasi Pembelajaran dan Evaluasi Belajar Ilmu Pengetahuan Alam (IPA) Kelas V Sekolah Dasar Berbasis Android. Skripsi, FT Universitas Mataram, 2017.

[7] S. Septian, Sistem Informasi Pembelajaran Dasar Anak Dibangun Sebagai Media Alternatif Dalam Pembelajaran Untuk Anak Retasdisi Mental Berbasis Android Pada Sekolah Luar Biasa.(SLB) C Karya Ibu Palembang. Skripsi Program Studi System Informasi, Fakultas Sains Dan Teknologi Universitas Islam Negeri Raden Fatah Palembang, 2017.

[8] S. Syaifullah, I. G. P. S. Wijaya, dan A. Y. Husodo, "Sistem Informasi Kepuasan Layanan Administrasi 
Akademik Berbasis IPA (Importance Performance Analysis) Studi Kasus Fakultas Teknik Universitas
Mataram," J. Comput. Sci. Informatics Eng., vol. 2, no. $1,2018$. 